\title{
Diagnostic Review of the Monitoring and Evaluation System of Uganda's Education Sector: Selected Findings and Discussion
}

\author{
Nathalie Holvoet (Corresponding author) \\ Institute of Development Policy and Management, University of Antwerp \\ Lange St. Annastraat 7, 2000 Antwerpen, Belgium \\ Tel: 32-3-265-5653Ｅ-mail: nathalie.holvoet@ua.ac.be \\ Liesbeth Inberg \\ Institute of Development Policy and Management, University of Antwerp \\ Lange St. Annastraat 7, 2000 Antwerpen, Belgium \\ Tel: 32-3-265-5992Ｅ-mail: liesbeth.inberg@ua.ac.be
}

Received: November 5, 2014 Accepted: November 27, 2014 Published: December 2, 2014

doi:10.5296/jet.v2i1.6720 URL: http://dx.doi.org/10.5296/jet.v2i1.6720

\begin{abstract}
While the world is not on track to reach the Education for All (EFA) goals aid to the education sector has been reduced. In a context of limited resources in which maximising student learning is a challenge, strengthening monitoring and evaluation (M\&E) systems is necessary, in order to make use of evidence and demonstrate results. This article argues in favour of an incremental approach to strengthening M\&E systems that starts from what exists locally. In doing this, an essential first step is a diagnosis of the existing M\&E system or arrangements that moves beyond technicalities and also focuses on the underlying institutional issues and the role of different stakeholders with different M\&E needs. This article presents the findings from such a diagnostic exercise of Uganda's education sector M\&E system. Our findings show that key elements of Uganda's education sector M\&E are already in place, though a number of challenges and weaknesses remain.
\end{abstract}

Keywords: monitoring and evaluation, educational policy, learning, accountability, aid, Uganda 


\section{Introduction}

At the Dakar World Education Forum in 2000 participants agreed upon the Dakar Framework for Action, which includes six Education for All (EFA) goals with targets for 2015. The 2013/14 EFA global monitoring report (UNESCO, 2014) clearly highlights that the world is not on track to reach any of the EFA goals in 2015. Nevertheless, donors are reducing their aid to the education sector, while at the same time the global financing gap is estimated to be 26 billion USD. According to Steer and Baudienville (2010), the education sector should attract more aid by making use of evidence, demonstrating results, enhancing aid effectiveness and using innovative financing mechanisms. In order to make use of evidence and demonstrate results, strengthening monitoring and evaluation (M\&E) systems in the education sector is necessary, especially in a context of limited resources in which maximising student learning is one of the greatest challenges (Hua \& Herstein, 2003).

The Fast Track Initiative, set up in 2002 with the aim to accelerate progress towards the EFA goals, was supposed to promote data collection and M\&E. In practice, however, the initiative has contributed little to the upgrading of data collection and $\mathrm{M} \& \mathrm{E}$, as only a small proportion of funds has been used to strengthen data reporting and use at country level. Moreover, the foreseen strengthening of education sector plans by including $M \& E$ and annual targets for measuring progress has been limited (Cambridge Education, Mokoro, and Oxford Policy Management, 2010). To correct for this, the successor of the Fast Track Initiative, the Global Partnership for Education (GPE), has elaborated an M\&E strategy and established a results framework that links objectives with specific assessment criteria and concrete activities (Global Partnership for Education, 2011). Due to the focus on the expansion of the partnership, however, support for education sector policy development and monitoring has been minimal so far (Global Partnership for Education, 2013).

The relative lack of attention to $\mathrm{M} \& \mathrm{E}$ is not unique to the Fast Track Initiative. A 2010 OECD/DAC report indicates that aid agencies increasingly acknowledge the importance of M\&E development in recipient countries, yet demonstrate relatively little strategic engagement in this area. While the need for further guidance in this field has been especially emphasised by M\&E units of aid agencies (OECD/DAC, 2010), so far the topic has remained underexplored in academic literature. We aim to contribute to this challenging and policy-relevant research agenda and invest, in particular, in the elaboration of a diagnostic instrument and stocktaking exercises of M\&E systems in various developing countries (Holvoet, Gildemyn, and Inberg, 2012; Holvoet \& Renard, 2007). This focus on diagnosis and stocktaking starts from the assertion that, regardless of the approach adopted, an important first step in any $M \& E$ capacity-building effort is to take stock of what already exists on the M\&E supply and demand side. This is consistent with the idea that small incremental changes to existing systems might be more feasible than radical and abrupt changes that seek to impose blueprints from the outside (see North, 1990). In this article we share selected findings of the application of our diagnostic tool to the M\&E system of Uganda's education sector. Uganda is an interesting case, as their education sector presently faces insufficient financial means combined with a decreasing quality of education, which necessitates the establishment of a sound M\&E system. In addition, the rationale for our case selection is also related to the fact that donors have played 
an active role in Uganda's education sector since the turn of the century. After the launch of the Education Strategic Investment Plan (1998) a Sector Wide Approach (SWAp), including the provision of sector budget support, was introduced into Uganda's education sector (Eilor, 2004). Within the SWAp framework, sector working groups and joint sector reviews are organised which are key to M\&E coordination and alignment. Finally, as several key elements of the M\&E system of Uganda's education sector are already in place, other sectors and countries could learn from their case.

While this article does not focus on the diagnostic framework as such, prior to discussing the findings with respect to Uganda's education sector M\&E system we set out with a short introduction to the diagnostic tool and provide as well details on data collection. The last section concludes.

\section{Methodology}

M\&E development is often narrowed down to a focus on technicalities (Bedi, Coudouel, Cox, Goldstein, and Thornton, 2006), while it is increasingly acknowledged that the organisational and institutional dimensions of $\mathrm{M} \& \mathrm{E}$ are often more influential and difficult to organise (Bamberger, 2010; Wood, Betts, Etta, Gayfer, Kabell, Ngwira, Sagasti, and Samaranayake, 2011). Therefore our diagnostic tool reviews the quality of M\&E systems according to six broad M\&E dimensions: (i) policy, (ii) indicators, data collection and methodology, (iii) organisation, (iv) capacity-building, (v) participation of non-governmental actors and (vi) use. In elaborating our tool, we were inspired by insights from, amongst others, the meta-evaluation literature (for example, Stufflebeam, 1974) and M\&E principles and guidelines, along with several existing M\&E assessment tools (see e.g. OECD/DAC, 2006; Bedi et al., 2006). The six dimensions of the sector M\&E diagnostic tool are subdivided into 34 questions (see Appendix 1) and assessed using the LEADS scoring system ${ }^{1}$ : little action (1), elements exist (2), action taken (3), largely developed (4) and sustainable (5) ${ }^{2}$. The scores obtained are not interpreted cardinally but used only to draw a picture of comparative strengths and weaknesses. This article focuses on the qualitative discussion of the findings.

Our study is based upon a combination of primary and secondary data collection. Secondary data includes academic literature and policy documents on M\&E systems, education sector M\&E, Uganda's education sector, donor roles and approaches in M\&E. Our documentary base was further supplemented with two specific rounds of primary data collection in the period 2011-2012 which were funded by Belgian development cooperation, one of the donors that provided budget support to Uganda's education sector at that time. We collected grey literature and policy documents and conducted semi-structured interviews with a broad range of stakeholders, involving actors that supply $\mathrm{M} \& \mathrm{E}$ information and actors that demand and use outputs from the M\&E system.

\section{Diagnosis of Uganda's Education Sector M\&E System: Selected Findings and Discussion}

The findings of the diagnostic review highlight that several key elements of Uganda's education sector M\&E system are already in place or largely developed. Comparing findings 
of the diagnostic review over the different dimensions, highlights that data collection, oversight/coordination, joint sector reviews score particularly well, while the reverse is true for M\&E capacity, feedback loops into planning, policy and budgeting, and use of M\&E outputs at local level (see also Appendix 1). In what follows we zoom into selected findings alongside the different dimensions of our diagnostic tool.

\subsection{Policy}

A comprehensive M\&E policy which outlines exactly what to monitor and evaluate, why, how and for whom is particularly important for the coordination of often largely fragmented sector M\&E arrangements. Within the Ministry of Education and Sports (MoES) such a 'grand design' exists (Ministry of Education and Sports, 2002), yet it dates back to 2002. Whilst the 2010-2015 Education Sector Strategic Plan (ESSP) does include an updated list of indicators and targets, other elements of the M\&E policy would also benefit from updating. The 2002 M\&E framework is a sound document, which provides an overview of what and why to monitor and evaluate, while also clearly distinguishing between monitoring on the one hand and the more analytically demanding evaluative activities on the other hand. While the M\&E framework emphasises the importance of learning/feedback and accountability, it does not highlight the possible tensions that might exist between the two main M\&E objectives ${ }^{3}$. As highlighted by several interviewees, over time the emphasis on 'accountability' has become more pronounced, at least on paper. This is, amongst others, obvious from the 2010-2015 Education Sector Strategic Plan (ESSP), which strongly emphasises the importance of 'accountability' and proposes several strategies combining downward and upwards accountability mechanisms (school management committees and inspection system).

While the M\&E framework is relatively well developed on paper, the implementation of the M\&E framework and M\&E elements of the ESSP has been limited in practice. Evaluation, for example, barely exists within the MoES (Office of the Prime Minister, 2012). According to several interviewees, this neglect of evaluation is due to a heavy monitoring and reporting burden, with different formats being used by different stakeholders. The emphasis on monitoring at the expense of evaluation is not a phenomenon which is unique to Uganda's education sector. A recent desk-based analysis of national M\&E systems in 20 Sub-Saharan Africa countries demonstrates that the majority of the reviewed M\&E systems have a similar bias towards monitoring (Holvoet et al., 2012). Within the context of a sequencing approach towards the setting-up of an M\&E system, such a predominant focus on monitoring may be a logical first step. However, there seems to be a general tendency for monitoring to crowd out evaluation, which is to some extent related to the increased donor-driven focus on performance monitoring and results-based management (see also Liverani \& Lundgren, 2007). A consequence of the focus on monitoring at the expense of evaluation is that the underlying reasons for (non)-performance are not revealed. While this is often politically more safe (Holvoet \& Rombouts, 2008), it hampers the realisation of the twin M\&E objectives of accountability and learning as well as the final objective of improvement of outcomes over time.

When it comes to dissemination of findings towards a wider audience, thus far no reporting 
and dissemination strategy exists that differentiates between targeted audiences. In addition, there is hardly any accountability of districts and schools to parents, the public and the ministry with respect to compliance with MoES norms and guidelines and educational performance (see Winkler \& Sondergaard, 2008), as school management committees and the inspection system have not functioned effectively thus far. This is also symptomatic of the generally noted breakdown of communities' and parents' involvement since the introduction of universal primary and secondary education (interviewees; Cambridge Education, 2011; Nishimura, Ogawa, Sifuna, Chimombo, Kunje, Ampiah, Byamughisha, Sawamura, and Yamada, 2009).

With the aim of addressing the existing accountability gap, a system of District League Tables was introduced in 2010 in order to track and compare the performance of different districts with respect to three indicators which change yearly. While this system might trigger upwards accountability, without proper data supervision or an appropriate control mechanism, side effects such as crowding-out and gaming are a real possibility ${ }^{4}$ (see Kalk, Paul, and Grabosch, 2010).

\subsection{Indicators, Data Collection and Methodology}

Indicators and data collection are generally among the most developed aspects of M\&E systems (Bedi et al., 2006; Booth \& Lucas, 2002; Holvoet \& Renard, 2007), which is also true to some extent in the case of Uganda's education sector. As elsewhere, this is largely driven by the increased emphasis that donors place on indicators and targets in their move towards budget support and the use of performance assessment frameworks. The influence of the education donors, among others, is evident from the list of indicators included in the Educator Sector Strategy Plan (ESSP), which largely overlaps with performance indicators and targets used in the Joint Assessment Framework. While the former is specifically used by education sector donors to assess performance against the undertakings agreed upon during the joint education (and sports) sector review, the latter includes indicators and related targets used by donors providing general budget support.

Sources of data collection have been identified for all the indicators, with the ministry's Educational Management Information System (EMIS) and its annual census being of particular significance. Sound sector management information systems are particularly important when addressing the widely observed phenomenon of the 'missing middle', which refers to a lack of attention for local service delivery, and which also seriously affects the 'evaluability' of sector programmes. In fact, in most countries (and under the auspices of donors), there is a bias towards data collection at the level of inputs (budgets and the quality of public finance management), final outcomes and impact (mainly MDGs) while less is known about the intervening levels located between the two extremes of the causal chain (Booth \& Lucas, 2002). It is these sector management information systems particularly which provide information on this missing middle of activities and their corresponding outputs and outcomes. While the incompleteness and unreliability of the Ugandan Education Management Information System (EMIS) data is still a challenge, data quality is generally improving (Winkler \& Sondergaard, 2008). Low response rates and incompleteness of information at (private) school level remain 
key problems, as does the tendency towards over reporting, which is related to the way in which the allocation of teachers and funds is determined on the basis of the self-reported enrolment data (Cambridge Education, 2010; interviewees). In order to improve EMIS data quality, a new technology system through which data is collected in a real time environment is being piloted in 20 districts. One of the advantages of the new system is the availability of real time data to inspectors. So far differences between, for example, number of students in EMIS and number of students counted during inspections are easily disputed by the head teacher as a large time lag usually exists between data collected during the annual census (usually only available one year later) and the inspection. Therefore the new EMIS is expected to contribute to the reduction of data inflation (interviewees).

In addition to the EMIS which is mainly focused on activity and output indicators, a multitude of other data sources exists, including the Uganda Population Survey of the Uganda Bureau of Statistics (UBOS) and the National Assessment of Progress in Education (NAPE), through which performance on learning outcomes included in the Joint Assessment Framework is assessed (Uganda National Examination Board 2011). While some of these monitoring exercises and data sources partly overlap, thus far data has not been cross-checked or triangulated (interviewees). Cross-reading between facility-based data (for instance EMIS and NAPE) on the one hand and household surveys on the other might be particularly interesting, as population-based surveys also include those sections of the population that are not currently within the education system. Cross-reading between data sources is also necessary to link performance on indicators that have been specified at different levels of the causal chain. This involves, among others, linking UBOS and/or NAPE data on intermediate, final outcomes and impact, with EMIS data on activities and outputs. It is especially this type of cross-reading and triangulation among data sources that is key to evaluation and analysis of underlying reasons for (non)-performance (see Rossi, Lipsey, and Freeman, 2004). In fact, various interviewees hinted at the fact that much of the data that is currently available and spread over various databases is not analysed at all. This analysis gap is to some extent related to the lack of analytical and evaluative capacity, which is also obvious from the meagre attention paid to quantitative and qualitative evaluation methodologies. While all of these more 'technocratic' limitations might partly explain the neglect of the more methodologically demanding evaluative studies, cross-reading between data sources also requires more coordination between, and oversight from, different ministries and institutes, which is often institutionally sensitive and not something which can be achieved overnight (see also Bamberger 1991).

\subsection{Organisation and Capacity}

It is increasingly acknowledged that more often than not it is the organisational and institutional dimensions rather than M\&E technicalities that are the Achilles heel of recipient countries' M\&E (Bedi et al., 2006; Wood et al., 2011). One of the crucial elements in this regard is the establishment of an appropriate institutional structure providing support, overview and coordination for the multitude of actors involved in data collection, reporting, analyses, feedback and use of M\&E findings. Within the MoES itself, coordination and oversight is in the hands of the M\&E unit, which is generally considered to be functioning 
well, though its location within the Education Planning and Policy Analysis Department might at times curtail its power. More specifically, while in principle this positioning stimulates the feedback loop to sector planning and policy-making, a hierarchically higher position for $\mathrm{M} \& \mathrm{E}$ could guarantee a certain level of independence which would be welcome for accountability purposes (interviewees).

For a sector M\&E system to function properly, it needs to be optimally linked with the statistical office, the overarching (cross-sector) national M\&E system (mostly positioned within finance or planning ministries), M\&E at district level and donor M\&E. As far as Uganda's education sector is concerned, the Ugandan statistical bureau (UBOS), which is perceived to be one of the most professional and transparent statistical offices in Africa (World Bank, 2010), plays an important role as it supplies data relevant for the education sector through surveys and censuses. In the near future, UBOS also envisages an expansion of its role in improving the quality of data collected at line ministries, while also streamlining management information systems across different line ministries. Though such high-level coordination among information systems of different line ministries might facilitate data collection at district level, a number of interviewees highlighted the existence of some resistance against this increased level of UBOS' involvement. This is particularly so in those line ministries which already have management information systems (such as the education and health sector) and which fear too much interference from centrally located institutes and ministries.

While upward integration of line ministries' $M \& E$ in the overarching central M\&E also used to be particularly complex in Uganda because of continuous reforms and partly overlapping mandates of, and competition among, different central-level actors (including the Office of the Prime Minister, the National Planning Authority and the Ministry of Finance and Economic Development), it seems that the Office of the Prime Minister has become the most powerful actor in central M\&E oversight and coordination among different line ministries. Within the Office of the Prime Minister itself, the coordination, monitoring and evaluation department has been elevated to directorate level (Oxford Policy Management, 2009) and its role in coordinating the drafting of the Government Annual Performance Report has increased its leverage over the line ministries. The line ministries' annual performance reports are the main inputs into the Presidential retreats where ministers and permanent secretaries discuss sector performance and thus function as a powerful incentive for data collection and use (see below). Besides triggering M\&E demand, the Office of the Prime Minister also invests in the M\&E supply side through the set-up of the Evaluation Facility and the proposal to allocate and ring-fence parts of sector budgets to monitoring and (particularly) evaluation.

For line ministries that lack any M\&E function, this M\&E champion and cheerleader role of the Office of the Prime Minister is particularly welcome. However, in line with what was suggested above, for other line ministries such as the MoES which have already established their own M\&E units, a more coercive mandate from the Office of the Prime Minister is more sensitive as it is likely that they will need to adjust their own M\&E structures and activities according to the Office of the Prime Minister directives. Additionally, too much power and control over M\&E from central agencies might also curtail the learning function of $M \& E$ within the line ministries themselves. If anything, the fact that control over M\&E is a 
sensitive issue which often involves fierce competition among different agencies is a widely observed phenomenon (see Bamberger, 1991).

The Education Sector Strategic Plan is silent with respect to existing M\&E capacities and needs, but other sources have specific views on the issue. A 2009 World Bank document considers Uganda's capacity to monitor education indicators such as enrolment rates, number of teachers, infrastructure and instructional material to be relatively strong (World Bank, 2009). The Office of the Prime Minister, however, is far more critical, and identifies the MoES as the only Ministry that does not have sufficient staff for M\&E and also draws attention to the fact that none of the M\&E staff have a certificate or diploma in M\&E (Office of the Prime Minister, 2012). While some of the four permanent staff members of the MoES' $\mathrm{M} \& \mathrm{E}$ unit might have gained significant experience and on-the-job-training in $\mathrm{M} \& \mathrm{E}$, they themselves emphasised the lack of analytical capacities which hampers the development of the evaluative component. Similarly, they also pointed out time and human resource constraints on investing in M\&E capacity development at decentralised levels, where it barely exists. Those M\&E capacity development initiatives that have taken place were not always adequately coordinated (BTC Uganda, 2012), and furthermore were concentrated mainly at central line ministry level, largely foregoing investment in M\&E (and more broadly education management) capacity at district level.

The lack of evaluative capacity at decentralised level is not unique to the education sector or the Ugandan context. In fact, district level M\&E is often considered to function merely as an outpost for central-level data collection and does not necessarily address local level implementation realities. This also applies to the Ugandan education sector where districts send quarterly work plans (for approval) and reports to the MoES, yet hardly receive any feedback with respect to the data that was locally collected and channelled upwards (interviewees). Quality of data is barely controlled and is not analysed locally for use in local-level decision-making which in itself discourages local level data collection (see also below).

As far as linkages between donors' M\&E exercises and the education sector M\&E system are concerned, donors share reports of their M\&E exercises with the ministry's M\&E unit. However, information from these studies has rarely been used within the MoES, although it is not the case that no instruments for coordination among donors and the MoES exist. Sector working groups are operational and focus on specific sub-sectors of the education sector or cross-cutting issues, including M\&E. The M\&E working group is one of the most active working groups and recently some new initiatives have been taken to increase coordination among donors' M\&E exercises and the sector M\&E system. Moving towards a more systematic exchange and joint identification of evaluation needs helps to counter the tendency of donor agencies to select topics for impact evaluation in an uncoordinated manner responding mainly to the interests of the individual donor agency (see Bamberger, 2010) and to provide feedback only to the evaluated projects or donor headquarters (OECD/DAC, 2010).

\subsection{Participation of Non-Government Actors}

The presence and functioning of an M\&E supply and demand outside of national government structures is generally considered to be important for the realisation of the key objectives of 
learning and accountability (see Gaventa \& Mc Gee, 2013; Wang \& Rakner, 2005). Outside government actors typically include parliament (supported by the Office of the Auditor General), civil society organisations and donors. In the case of Uganda's education sector, the influence of donors is particularly strong. The Joint Assessment Framework which is used by budget support donors has, for instance, been an important instrument in guiding $\mathrm{M} \& \mathrm{E}$ within the MoES. Additionally, education donors actively participate in sector working groups and sector reviews as well as budget and planning workshops, while they also support the reporting and M\&E system through financial and technical inputs (Hedger, Williamson, Muzoora, and Stroh, 2010). Though initiatives to improve data collection and monitoring have not been adequately coordinated in the past, the level of coordination among education donors in the area of M\&E is currently on the increase. Furthermore, while the recent shift of a number of sector budget support donors towards project support in the education sector could jeopardise this tendency towards more coordination, on the contrary it may boost exchange due to the fact that triangulation of information and experience at project and sector level may be interesting for both types of donors.

Whilst M\&E is usually explicitly included in the parliament's mandate, in reality few parliaments are actively involved in M\&E (see Republic of Uganda, 2011a). Whereas the Ugandan parliament is not considered an effective watchdog (Wild \& Domingo, 2010; Williamson \& Dom, 2010), it has recently adopted a more critical stance which is, according to some of our interviewees, related to the involvement of younger and more critical parliamentarians who have a more developed reading culture, something which also increases the probability that information from M\&E reports is read and used. However, the recent split of the Social Service Committee into a health and an education committee might be detrimental to the quality of debate and follow-up in the education sector, as the majority of the active parliamentarians have chosen to become members of the health committee (interviewees). It is through the Office of the Auditor General in particular, and more specifically its annual financial and value-for-money audits, that Parliament gets involved in the monitoring and management of public finances. While Wild and Domingo (2010) hinted at the fact that the Office of the Auditor General was poorly resourced and, even more importantly, lacked the necessary independence, others highlighted that it has become stronger through successful tailor-made capacity building initiatives (Hedger at al., 2010). If anything, the implementation of recommendations from the Office of the Auditor General is undermined by a serious backlog of parliamentary discussion of audit reports (interviewees).

While civil society organisations active in Uganda's education sector are considered weak with respect to voice and influence in national debates (interviewees; Purcell, 2010), several examples exist of non-governmental organisations being actively involved in education sector M\&E. The Uganda Debt Network, for example, coordinates civil society monitoring of Poverty Action Fund activities in the districts (Office of the Prime Minister, 2012) and leads an experiment into local downward accountability. In fact, findings from various studies have demonstrated that where transparency towards and involvement of communities and parents in school management is higher, this contributes to better quality education (see Nishimura et al., 2009). Uwezo, another initiative of citizen-led accountability, hosted in the Uganda 
National NGO forum, conducts annual learning assessments which complement government education assessments (Uwezo Uganda ,2011). While cross-reading and combinations of such citizen-led accountability exercises on the one hand, and within-government M\&E exercises on the other hand could be particularly useful and effective (see McGee \& Gaventa, 2011), they have thus far mainly led to a discussion around the validity of the methodologies used by Uwezo (interviewees). In order to avoid such ex-post discussions on issues of validity, it might be worthwhile for civil society organisations to partner with universities and research institutes which mostly have a comparative advantage in terms of methodological and analytical capacities.

It is particularly such linkages and networks between different types of (domestic) accountability actors which have thus far remained underexplored. This is somewhat surprising as different actors tend to have different comparative advantages which might complement each other. Civil society organisations for instance tend to have easier access to local level data (reality checks), parliament has more access to the political arena and donors to the policy level while universities generally have more analytical capacity. This allows for useful triangulation of data from various sources, and may also stimulate discussion and counter-analysis. Networking among different M\&E actors (also beyond the education sector) might especially be stimulated through the recent revamping of the Uganda Evaluation Society, which aims to organise and upgrade national M\&E capacity.

\subsection{Use of M\&E Outputs}

While it has been increasingly acknowledged that the use of M\&E findings and the creation of an M\&E demand side is vital for the institutionalisation and sustainability of an $\mathrm{M} \& \mathrm{E}$ system (Mackay, 2007), on the ground there is relatively little evidence of M\&E findings being systematically used for learning and accountability, particularly at local level.

The main output of MoES' M\&E section is the Education and Sports Sector Annual Performance report, which is a rich source of information (Hedger et al., 2010) and a crucial input into the joint sector review. The analytical quality, however, is still relatively low, as performance and expenditure are not systematically linked (Hedger et al., 2010), results and outcomes are rarely compared to targets and/or baselines and the analysis of causes of (non) performance is either lacking or shallow. This weakness in terms of analytical quality should not come as a surprise, and is related to the bias towards monitoring noted earlier. While such a lack of analytical depth is an important stumbling block in terms of use, M\&E findings are also often not available in a timely manner in order to feed into the next budgetary cycle. In an attempt to address this issue, the Office of the Prime Minister currently urges line ministries to provide their annual performance reports one month earlier (interviewees). These performance reports are also the basis for the half yearly cabinet retreats in which performance of different line ministries and agencies are compared and discussed. On the ground, this 'naming and shaming' event has clearly triggered different line ministries' attention for data and performance monitoring in particular.

While more focus on 'performance' and 'results' is welcomed, there are also a number of challenges related to performance-based measurement and management which have been 
widely documented in the public administration and evaluation literature (see, for example, Mayne, 2007). While it is beyond the scope of this article to discuss all the pitfalls of performance measurement and management, we hint at a number of concerns that might be particularly valid in the context of this study. A first concern is that the lack of data supervision or control might lead to gaming and unreliable data. Second, M\&E systems that need to deliver performance information are often driven towards monitoring for upward accountability to the detriment of satisfying their own evaluation and learning needs (see Flint, 2003). As mentioned above, this might also become a real possibility in Uganda's education sector when more centralised M\&E needs (Office of the Prime Minister) come to dominate over sector (MoES) and (particularly) local M\&E needs. This crowding-out is particularly evident at district level where data collection exercises are mainly driven by upward accountability needs and rarely used for local-level learning and accountability, which does not incentivise high-quality local level data collection. It is from this vantage point in particular that increased involvement of citizens and communities in local $\mathrm{M} \& \mathrm{E}$ exercises might be important in order to fill the gap. An interesting initiative from this perspective is that of the so-called 'barazas', which create an interface for discussion and negotiation among public service users of health, education and water and sanitation services (citizens), public service providers (local government) and public service decision-makers (central and local government) (Republic of Uganda, 2011b).

As far as education sector donors are concerned, our findings show that they increasingly align themselves with the existing national M\&E arrangements. While the increased use of existing national M\&E outputs tends to lower the burden of additional parallel donor M\&E exercises, it simultaneously also adds to the above mentioned phenomenon of unbalanced development of M\&E systems. Donors tend to be mainly interested in input, final outcome and impact (MDG) indicators, something which has also led to a predominant focus and support for these levels of data collection at the detriment of developing sector management information systems. However, outcome and impact data only change very slowly and there are often problems with attribution when trying to link impact data to outputs and intermediate outcomes (Shaffer, 2012).

While various interviewees involved in $\mathrm{M} \& \mathrm{E}$ at national and local level highlight that systematic feedback loops of M\&E outputs to sector and local-level planning and budgeting do not exist, there are useful cases of ad-hoc use of M\&E findings. A renowned Ugandan example of influential M\&E findings is the 1996 Public Expenditure Tracking Survey, which highlighted that only $13 \%$ of earmarked funds reached the areas they were to be spent in and this subsequently led to the obligation to publish all funding allocations in working plans of the Poverty Action Fund (see World Bank 2004). A more recent example of ad-hoc use is the study on the efficiency of Uganda's public education system commissioned by the MoES, which fed into the updated Education Sector Strategy Plan. While these changes in policies and laws are noteworthy, they do not guarantee effective changes on the ground as they have to be realised within the context of Uganda's well-known implementation gap.

Finally, it is also possible that some incidences of use have escaped our attention. In fact, the type of use we have captured in our research is mainly direct/instrumental use while there are 
also less tangible types of evaluation use and influence involving conceptual use and enlightenment, bringing new ideas into the policy arena (see Weiss, 1999). While such forms of indirect use/influence tend to be more prevalent, more in-depth and long-term field research is needed to adequately grasp their significance.

\section{Conclusion}

In order to trigger accountability and learning in the education sector, developing and strengthening the monitoring and evaluation system is necessary. This holds especially for the case of Uganda's education sector, which is faced with insufficient financial means and a decreasing quality of education. Starting from the assertion that small incremental changes are more viable than imposing blueprints from the outside, an important first step is to take stock of the M\&E arrangements and capacity that already exist, both at the M\&E supply and demand side. This is exactly what our study does. In order to counter the criticism that M\&E is often narrowed down to a focus on technicalities, our diagnosis captures six broad dimensions of M\&E systems, i.e. policy; indicators, data collection and methodology; organisation (structure and linkages); capacity; participation of non-government actors; and use of M\&E outputs. We draw upon a combination of secondary data and primary data collected through semi-structured interviews with various actors involved in Uganda's education sector monitoring and evaluation.

Our findings hint at the fact that Uganda's education sector M\&E system is already satisfactorily developed, yet there remain a number of challenges and weaknesses, which are also often encountered in other sectors and countries. Uganda's education sector M\&E system is a text-book example of an M\&E system that is heavily skewed towards monitoring at the detriment of evaluation. There is a multitude of (partly overlapping) monitoring exercises while almost no analysis is done of the data collected. This neglect of evaluation is also not entirely surprising, for several reasons. First, evaluation is methodologically more challenging, particularly in settings where policies and programmes have not been conceptualised with a programme theory in mind and where indicators are thus not specified in terms of inputs, outputs, outcomes and impact, let alone linked together in some form of logic chain. Linkages between different levels of indicators have to some extent also been jeopardised by donors' extensive focus and support for data collection with respect to the two extremes of the causal chain, i.e. inputs and budgets on the one hand and final outcomes and impact (particularly MDGs) on the other. There is much less attention for the in-between, i.e. the missing-middle of sector ministries' activities and outputs, which are mainly captured through sector management information systems. While the Ugandan education sector management information system has strongly improved over the years, there are still problems related to data quality and, as elsewhere, outcome and impact data collected through surveys administered by the Ugandan Bureau of Statistics is still considered to be of higher quality and reliability.

Second, evaluation is also more politically challenging than monitoring, certainly in those cases where the focus is on aggregate monitoring, which tends to cover differences in results among different (gender-income-region-class-rural/urban) layers of society, leaving, in 
addition, the underlying reasons and responsibilities for non-performance underexplored.

Third, cross-reading and linking data on indicators specified at different levels of the causal chain, which is key to evaluative analysis, also necessitates co-ordination amongst central level ministries and institutes, such as the Ministry of Finance, Office of the Prime Minister, Ugandan Bureau of Statistics and line ministries, such as the Ministry of Education. It is, in particular, such coordination among different ministries that proves to be the Achilles heel of many M\&E systems. This is, for instance, amongst others evident from subsequent rounds of OECD/ DAC Paris Declaration Surveys (OECD/ DAC 2007, 2008; OECD, 2011) which have demonstrated that coordination among largely fragmented components of M\&E systems is particularly problematic. Again, this does not entirely come as a surprise; coordination and oversight in $\mathrm{M} \& \mathrm{E}$ is often institutionally and politically sensitive for the reason that control over monitoring, and particularly evaluation, conveys power over resources and other agencies.

While Uganda's education sector M\&E system currently scores relatively well on coordination and oversight, some tensions might arise as the Office of the Prime Minister and the Ugandan Bureau of Statistics are taking up a much more coercive mandate in terms of central level coordination, oversight and quality control. While more streamlining and coordination at different levels of the system is necessary and useful, there is simultaneously a need to ensure that there remains enough room for coping with M\&E needs that are specific to a particular level. In reality, coordination often goes hand in hand with a predominance of higher-level information needs over lower-level M\&E needs. This is true at various levels with international (donor) information needs crowding out national needs, central-level (Office of the Prime Minister) needs overwhelming line ministries' needs and local district and school level M\&E being driven largely by data collection needs decided upon at line ministry level. It is important to acknowledge these tensions when elaborating a sector M\&E system and to seek a balance among different needs and perspectives (see also Riddell, 1999). This might be realised, for instance, through the involvement of local level stakeholders when deciding upon sector indicators and data collection needs. Disregarding this and only considering local level M\&E as outposts of central level data collection processes leads to local M\&E not being used for local level decision-making and accountability which will, in the long run, undermine local level M\&E.

The bias towards the processes and systems of central and line ministries at the expense of local level service delivery management and M\&E systems, has to some extent also been aggravated further through sector budget support. While sector budget support has contributed positively to an increased level of coordination among donors and alignment with the country's own education sector policies and systems, it has predominantly focused on sector level policies, processes and systems. Although the current shift back from sector to project support obviously puts a strain upon the existing level of harmonisation and alignment, it simultaneously offers opportunities for a better grasp (again) of local level implementation realities. What might be particularly valuable for the joint sector M\&E working group is to create a forum for exchange and triangulation among sector budget support donors with easier access to sector level data and project donors who tend to be closer to local level field realities. If anything, the withdrawal from sector budget support will most likely lead to an upsurge of project M\&E, 
which itself is not negative as it may help to fill the evaluation gap. Yet, in order to maximise the learning potential of these evaluative exercises beyond individual donor agencies and reduce transaction costs, joint selection or at least coordination of evaluation objects will be useful, as well as the set up of a feedback mechanism for M\&E findings to feed into the national M\&E system. This will also necessitate changes in the organisation of evaluation at the level of aid-agency headquarters and, more specifically, in the relationships between the field and headquarters (see also Liverani and Lundgren 2007). Such renegotiations might be not straightforward against the current backdrop of increased financial austerity in many European donor countries, which has induced a more questioning attitude towards aid modalities such as budget support that align with recipient countries' systems and where control over spending, implementation and $M \& E$ is thus lesser. In order to prevent individual donor agencies from restarting parallel stand-alone donor-driven $\mathrm{M} \& \mathrm{E}$, more attention (and investment) will be needed for systemic $M \& E$ issues on the agenda of $M \& E$ joint sector working groups and joint education sector reviews.

While donors have given an important impetus to education sector $\mathrm{M} \& \mathrm{E}$ development in Uganda, it is as important to complement this with a nationally driven M\&E demand, which goes beyond the aid-driven demand for M\&E. In doing this, domestic accountability actors such as parliament, civil society, research institutes, and academia are important. For those donors wishing to invest in domestic accountability, it might be interesting to experiment with portfolio approaches. In this scenario, investment in the M\&E capacities of accountability actors is combined with increasing the room to manoeuvre for these actors, as well as with using information from the local level monitoring exercises in their (donors) own policy dialogue with government at sector level.

\section{Notes}

1) See World Bank (2007) for more information on and application of the LEADS method.

2) For an elaborate discussion on the sector diagnostics framework and a full overview of findings, see Holvoet and Inberg (2012).

3) While accountability necessitates a certain degree of independence and autonomy, learning and feedback often benefits more from a certain degree of functional integration into decision-making and operational arenas (Valadez and Bamberger, 1994).

4) 'Crowding-out' effect is the diminishing or erasing of intrinsic motivation due to external rewards and 'gaming' is the focus on indicators that are in the system thereby neglecting non rewarded indicators or falsification of results to maximise reward (see Kalk et al., 2010).

\section{References}

Bamberger, M. (1991). The Politics of Evaluation in Developing Countries. Evaluation and Program Planning, 14, 325-39. http://dx.doi.org/10.1016/0149-7189(91)90015-9

Bamberger, M. (2010). Institutionalising Impact Evaluation. A key element in strengthening country-led monitoring and evaluation systems. In M. Segone (Ed.), From Policies to Results. 
Developing capacities for country monitoring and evaluation systems (pp. 189-217). Geneva: UNICEF.

Bedi, T., Coudouel, A., Cox, M., Goldstein, M., \& Thornton, N. (2006). Beyond the Numbers. Understanding the Institutions for Monitoring Poverty Reduction Strategies. Washington, DC: World Bank.

Booth, D., \& Lucas, H. (2002). Good Practice in the Development of PRSP Indicators and Monitoring Systems (ODI Working Paper 172). London: Overseas Development Institute.

Bratton, M. (2007). Formal vs. Informal Institutions in Africa. Journal of Democracy, 18(3), 96-110. http://dx.doi.org/10.1353/jod.2007.0041

BTC Uganda. (2012). Progress Report \#2, Education Sector Budget Support (ESBS). Kampala: BTC Uganda.

Burton, P. (2006) Modernising the policy process: making policy research more significant. Policy Studies, 27(3), 173-195. http://dx.doi.org/10.1080/01442870600885974

Cambridge Education. (2010). Fast Track Initiative Appraisal Report: Updated Education Sector Strategic Plan 2010-2015 (Final draft September 2010). Kampala: Government of Uganda, Ministry of Education and Sports and Education Development Partners.

Cambridge Education. (2011). Primary Education Systems Analysis - Final. Cambridge: Cambridge Education.

Cambridge Education, Mokoro, \& Oxford Policy Management. (2010). Mid-Term Evaluation of the EFA Fast Track Initiative. Final Synthesis Report. Volume 1 - Main Report. Cambridge: Cambridge Education.

Eilor, J. (2004). Education and the sector-wide approach in Uganda. Paris: UNESCO, International Institute for Educational Planning.

Flint, M. (2003). Easier Said Than Done: A review of results-based management in multilateral development institutions. London: Department for International Development.

Gaventa, J., \& Mc. Gee, R. (2013). The Impact of Transparency and Accountability Initiatives. Development Policy Review, 31(S1), s3-s28. http://dx.doi.org/10.1111/dpr.12017

Global Partnership for Education. (2011). The Case for Investment (2011-2014). Washington DC.: Global Partnership for Education.

Global Partnership for Education. (2013). Results for Learning Report 2013. Facing the Challenges of Data, Financing and Fragility. Washington DC.: Global Partnership for Education.

Hedger, E., Williamson, T., Muzoora, T., \& Stroh, J. (2010). Sector Budget Support in Practice. Case Study Education Sector in Uganda. London: Overseas Development Institute, Oxford: Mokoro.

Holvoet, N., \& Inberg, L. (2012). Sector Monitoring and Evaluation Systems in the context of 
Changing Aid Modalities: The Case of Uganda's Education Sector (field study report). Antwerp: University of Antwerp, Institute of Development Policy and Management

Holvoet, N., \& Renard, R. (2007). Monitoring and Evaluation under the PRSP: Solid rock or quicksand? Evaluation and Program Planning, 30, 66-81. http://dx.doi.org/10.1016/j. evalprogplan.2006.09.002

Holvoet, N., \& Rombouts, H. (2008). The challenge of monitoring and evaluation under the new aid modalities: experiences from Rwanda. Journal of modern African studies, 46, 577-602 http://dx.doi.org/10.1017/S0022278X08003492

Holvoet, N., Gildemyn, M., \& Inberg, L. (2012). Taking stock of Monitoring and Evaluation Arrangements in the Context of Poverty Reduction Strategy Papers: Evidence from 20 Aid-Dependent Countries in Sub-Saharan Africa'? Development Policy Review, 30(6), 749-772 (http://dx.doi.org/10.1111/j.1467-7679.2012.00597.x)

Hua, H., \& Herstein, J. (2003). Education Management Information System (EMIS): Integrated Data and Information Systems and Their Implications in Educational Management (Paper presented at the Annual Conference of Comparative and International Education Society, New Orleans, USA).

Kalk, A., Paul, F. A., \& Grabosch, E. (2010). 'Payment for performance' in Rwanda: does it pay off? Tropical Medicine and International Health, 15(2), 182-190. http://dx.doi.org/10.1111/j.1365-3156.2009.02430.x

Liverani, A., \& Lundgren, H. E. (2007). Evaluation Systems in Development Aid Agencies. An Analysis of DAC Peer Reviews 1996-2004. Evaluation, 13(2), 241-256. http://dx.doi.org/10.1177/1356389007075226

Mackay, K. (2007). How to Build M\&E Systems to Support Better Government. Washington, DC: World Bank, Independent Evaluation Group. http://dx.doi.org/10.1596/978-0-82137191-6

Mayne, J. (2007). Challenges and Lessons in Implementing Results-Based Management. Evaluation, 13(1), 87-109. http://dx.doi.org/10.1177/1356389007073683

McGee, R., \& Gaventa, J. (2011). Shifting Power? Assessing the Impact of Transparency and Accountability Initiatives. Brighton: Development Research Centre Citizenship, Participation and Accountability and Institute of Development Studies.

Ministry of Education and Sports. (2002). Monitoring and Evaluation Framework for the Education Sector. Kampala: Ministry of Education and Sports, Education Planning Department.

Ministry of Education and Sports. (2011). The Education and Sports Sector Annual Performance Report, covering the period 1st July 2010 - 30th June 2011. Kampala: Ministry of Education and Sports, Education Planning and Policy Analysis Department, M\&E Section.

Ministry of Education and Sports. (2012a). Evaluating and improving the quality of 
education. Kampala: Ministry of Education and Sports, Directorate of Education Standards.

Nishimura, M., Ogawa, K., Sifuna, D. N., Chimombo, J., Kunje D., Ampiah J. G., ... Yamada, S. (2009). A Comparative Analysis of Universal Primary Education Policy in Ghana, Kenya, Malawi, and Uganda. Journal of International Cooperation in Education, 12(1), 143-158.

North, D. C. (1990). Institutions, Institutional Change and Economic Performance. Cambridge: Cambridge University Press. http://dx.doi.org/10.1017/CBO9780511808678

OECD. (2011). Aid Effectiveness 2005-10: Progress in implementing the Paris Declaration. Paris: OECD.

OECD/DAC. (2006). Evaluation Systems and Use. A working tool for peer reviews and assessments. Paris: OECD/DAC.

OECD/DAC. (2007). 2006 Survey on Monitoring the Paris Declaration. Overview of the Results. Paris: OCED/DAC.

OECD/DAC. (2008). 2008 Survey on Monitoring the Paris Declaration. Making aid more effective by 2010. Paris: OECD/DAC.

OECD/DAC. (2010). Development Evaluation Resources and systems: A study of network members. Paris: OECD/DAC.

Office of the Prime Minister. (2012). A Rapid Review of Public Expenditure on Monitoring and Evaluation across the Government of Uganda, draft report. Kampala: Office of the Prime Minister.

Oxford Policy Management. (2009). Joint review of DFID and EC support to government monitoring and evaluation functions in Uganda. Oxford: Oxford Policy Management.

Purcell, R. (2010). Mid-Term Evaluation of the EFA Fast Track Initiative. Country Desk Study: Uganda. Cambridge: Cambridge Education, Oxford: Mokoro and Oxford Policy Management.

Republic of Uganda. (2011a). Phase II Evaluation of the Implementation of the Paris Declaration in Uganda, final report. Kampala: Republic of Uganda, Office of the Prime Minister.

Republic of Uganda. (2011b). Countrywide Implementation of the Baraza initiative Baraza report for 24 districts. Kampala: Republic of Uganda, Office of the Prime Minister.

Rossi, P. H., Lispey M. W., \& Freeman, H. E. (2004). Evaluation: A Systematic Approach (seventh edition). Thousand Oaks: Sage.

Shaffer, P. (2012). Demand-Side Challenges to Poverty Monitoring and Assessment Systems: Illustrations from Tanzania. Development Policy Review, 30(1), 29-48. http://dx.doi.org/10.1111/j.1467-7679.2012.00558.x

Steer, L., \& Baudienville, G. (2010). What drives donor financing of basic education? (ODI Project Briefing 39). London: Overseas Development Institute. 
Stufflebeam, D. L. (1974). Meta-evaluation (Occasional Paper Series 3). Kalamazoo: MI, Western Michigan University Evaluation Center.

UNESCO. (2014). EFA Global Monitoring Report 2013/14. Teaching and Learning: Achieving quality for all. Paris: UNESCO.

Uwezo Uganda. (2011). Are Our Children Learning? (Annual Learning Assessment Report). Kampala: Uwezo Uganda.

Valadez, J., \& Bamberger, M. (1994) Organizational and Management Issues in Programme Evaluation. In J. Valadez \& M. Bamberger (Eds.), Monitoring and Evaluating Social Programmes in Developing Countries: A Handbook for Policymakers, Managers and Researchers. Washington, DC.: World Bank. http://dx.doi.org/10.1596/0-8213-2989-8

Wang, V., \& Rakner, L. (2005). The accountability function of supreme audit institutions in Malawi, Uganda and Tanzania. Bergen: Chr. Michielsen Institute.

Weiss, C. (1999). The Interface Between Evaluation and Public Policy. Evaluation, 5(4), 468-86. http://dx.doi.org/10.1177/135638909900500408

Wild, L., \& Domingo, P. (2010). Accountability and Aid in the Health Sector. London: Overseas Development Institute and World Vision.

Williamson, T., \& Dom, C. (2010). Sector Budget Support in Practice (Synthesis Report). London: Overseas Development Institute, Oxford: Mokoro.

Winkler, D., \& Sondergaard, L. (2008). The Efficiency of Public Education in Uganda. Washington, DC.: World Bank.

Wood, B., Betts, J., Etta, F., Gayfer, J., Kabell, D., Ngwira, N., Sagasti, F., Samaranayake, M. (2011). The Evaluation of the Paris Declaration (Final Report). Copenhagen: Danish Institute for International Studies.

World Bank. (2004). Influential Evaluations. Evaluations that Improved Performance and Impacts of Development Programs. Washington, DC.: World Bank, Operations Evaluation Department.

World Bank. (2007). Results-Based National Development Strategies Assessment and Challenges Ahead. Washington. DC: World Bank.

World Bank. (2009). Project Appraisal Document for the proposed credit in the amount of SDR 99 Million (US\$ 150 Million Equivalent) to the Republic of Uganda for a Post Primary Education and Training Adaptable Program Lending (apl 1) Project in Support of the First Phase of the Uganda Post Primary Education and Training Program, March 5, 2009. Washington, DC.: World Bank.

World Bank. (2010). International Development Association, International Finance Corporation and Multilateral Investment Guarantee Agency Country Assistance Strategy for the Republic of Uganda for the Period FY 2011-2015. Washington DC.: International Development Association, International Finance Corporation and Multilateral Investment 
Guarantee Agency.

World Education Forum. (2000). The Dakar Framework for Action. Education for All: Meeting our Collective Commitments. Adopted by the World Education Forum, Dakar, Senegal, 26-28 April 2000.

\section{Appendix}

The sector M\&E system assessment tool: dimensions, questions and scoring for Uganda's education sector

\begin{tabular}{|c|c|c|c|}
\hline & Topics & Question & Score $^{1}$ \\
\hline \multicolumn{4}{|c|}{ 1. Policy } \\
\hline 1 & M\&E plan & $\begin{array}{l}\text { Is there a comprehensive M\&E plan, indicating what to evaluate, } \\
\text { why, how, and for whom? }\end{array}$ & 3 \\
\hline 2 & $M$ versus $\mathrm{E}$ & $\begin{array}{l}\text { Is the difference and relationship between } \mathrm{M} \text { and } \mathrm{E} \text { clearly } \\
\text { spelled out? }\end{array}$ & 3 \\
\hline 3 & $\begin{array}{l}\text { Autonomy \& } \\
\text { impartiality } \\
\text { (accountability) } \\
\end{array}$ & $\begin{array}{l}\text { Is the need for autonomy and impartiality explicitly mentioned? } \\
\text { Does the M\&E plan allow for tough issues to be analysed? Is } \\
\text { there an independent budget? }\end{array}$ & 3 \\
\hline 4 & Feedback & $\begin{array}{l}\text { Is there an explicit and consistent approach to reporting, } \\
\text { dissemination and integration? }\end{array}$ & 2 \\
\hline 5 & $\begin{array}{l}\text { Alignment, } \\
\text { planning \& } \\
\text { budgeting }\end{array}$ & Are $M \& E$ results integrated in planning and budgeting? & 3 \\
\hline \multicolumn{4}{|c|}{ 2. Indicators, data collection and methodology } \\
\hline 6 & $\begin{array}{l}\text { Selection of } \\
\text { indicators }\end{array}$ & $\begin{array}{l}\text { Is it clear what to monitor and evaluate? Is there a list of } \\
\text { indicators? Are sector indicators harmonised with the PRSP } \\
\text { indicators? }\end{array}$ & 3 \\
\hline 7 & $\begin{array}{l}\text { Quality of } \\
\text { indicators }\end{array}$ & $\begin{array}{l}\text { Are indicators SMART (specific, measurable, achievable, } \\
\text { relevant, time-bound)? Are baselines and targets attached? }\end{array}$ & 3 \\
\hline 8 & Disaggregation & $\begin{array}{l}\text { Are indicators disaggregated by sex, region or socio-economic } \\
\text { status? }\end{array}$ & 3 \\
\hline 9 & Selection criteria & $\begin{array}{l}\text { Are the criteria for the selection of indicators clear? Is it clear } \\
\text { who is involved in the selection? }\end{array}$ & 2 \\
\hline 10 & Priority setting & $\begin{array}{l}\text { Is the need to set priorities and limit the number of indicators to } \\
\text { be monitored acknowledged? }\end{array}$ & 3 \\
\hline 11 & Causality chain & $\begin{array}{l}\text { Are different levels of indicators (input-output-outcome-impact) } \\
\text { explicitly linked (program theory)? (vertical logic) }\end{array}$ & 2 \\
\hline 12 & $\begin{array}{l}\text { Methodologies } \\
\text { used }\end{array}$ & $\begin{array}{l}\text { Is it clear how to monitor and evaluate? Are methodologies well } \\
\text { identified and mutually integrated? }\end{array}$ & 2 \\
\hline 13 & Data (collection) & $\begin{array}{l}\text { What is de quality of the collected data (reliability)? Are sources } \\
\text { of data collection clearly identified? Are indicators linked to } \\
\text { sources of data collection? (horizontal logic) }\end{array}$ & 4 \\
\hline \multicolumn{3}{|c|}{ 3a. Organisation: structure } & \\
\hline
\end{tabular}




\begin{tabular}{|c|c|c|c|}
\hline 14 & $\begin{array}{l}\text { Coordination and } \\
\text { overview }\end{array}$ & $\begin{array}{l}\text { Is there an appropriate institutional structure for coordination, } \\
\text { support, overview, analyses of data and feedback at sector level? } \\
\text { With different stakeholders? What is its location? }\end{array}$ & 4 \\
\hline 15 & $\begin{array}{l}\text { Joint Sector } \\
\text { Review }\end{array}$ & $\begin{array}{l}\text { Does the JSR cover accountability and learning needs for both } \\
\text { substance and systemic issues? What is the place/linkage of the } \\
\text { JSR within the sector M\&E system? Does the JSR promote the } \\
\text { reform agenda of the Paris Declaration? }\end{array}$ & 4 \\
\hline 16 & $\begin{array}{l}\text { Sector working } \\
\text { groups }\end{array}$ & $\begin{array}{l}\text { Are sector working groups active in monitoring? Is their } \\
\text { composition stable? Are various stakeholders represented? }\end{array}$ & 4 \\
\hline 17 & Ownership & $\begin{array}{l}\text { Does the demand for (improvement of the) M\&E system come } \\
\text { from the sector ministry, a central ministry (e.g. ministry of } \\
\text { planning or finance) or from external actors (e.g. donors)? Is } \\
\text { there a highly placed 'champion' within the sector ministry who } \\
\text { advocates the (strengthening of the) M\&E system? }\end{array}$ & 4 \\
\hline 18 & Incentives & $\begin{array}{l}\text { Are incentives (at central and local level) used to stimulate data } \\
\text { collection and data use? }\end{array}$ & 3 \\
\hline \multicolumn{4}{|c|}{ 3b. Organisation: linkages } \\
\hline 19 & $\begin{array}{l}\text { Linkage with } \\
\text { statistical office }\end{array}$ & $\begin{array}{l}\text { Is there a link between sector M\&E and the statistical office? Is } \\
\text { the role of the statistical office in sector M\&E clear? }\end{array}$ & 3 \\
\hline 20 & $\begin{array}{l}\text { 'Horizontal' } \\
\text { integration }\end{array}$ & $\begin{array}{l}\text { Are there M\&E units in different sub-sectors and } \\
\text { semi-governmental institutions? Are these properly linked to the } \\
\text { sector's central unit? }\end{array}$ & 3 \\
\hline 21 & $\begin{array}{l}\text { 'Vertical' upward } \\
\text { integration }\end{array}$ & $\begin{array}{l}\text { Is the sector M\&E unit properly linked to the central M\&E unit } \\
\text { (PRS monitoring system)? }\end{array}$ & 4 \\
\hline 22 & $\begin{array}{l}\text { 'Vertical' } \\
\text { downward } \\
\text { integration }\end{array}$ & $\begin{array}{l}\text { Are there } M \& E \text { units at decentralised levels and are these } \\
\text { properly linked to the sector M\&E unit? }\end{array}$ & 3 \\
\hline 23 & Link with projects & $\begin{array}{l}\text { Is any effort being made to coordinate with donor } \mathrm{M} \& \mathrm{E} \\
\text { mechanism for projects and vertical funds in the sector? }\end{array}$ & 3 \\
\hline \multicolumn{3}{|c|}{ 4. Capacity } & \\
\hline 24 & Present capacity & $\begin{array}{l}\text { What is the present capacity of the M\&E unit at central sector } \\
\text { level, sub-sector level and decentralised level (e.g. fte, skills, } \\
\text { financial resources)? }\end{array}$ & 2 \\
\hline 25 & $\begin{array}{l}\text { Problem } \\
\text { acknowledgement }\end{array}$ & Have current weaknesses in the system been identified? & 2 \\
\hline 26 & $\begin{array}{l}\text { Capacity-building } \\
\text { plan }\end{array}$ & $\begin{array}{l}\text { Are there any plans/activities for remediation? Do these include } \\
\text { training, appropriate salaries, etc.? }\end{array}$ & 2 \\
\hline \multicolumn{4}{|c|}{ 5. Participation of non-government actors } \\
\hline 27 & Parliament & $\begin{array}{l}\text { Is the role of parliament properly recognised, and is there } \\
\text { alignment with parliamentary control and overview procedures? } \\
\text { Does parliament participate in Joint Sector Reviews and/ or } \\
\text { sector working groups? }\end{array}$ & 3 \\
\hline 28 & Civil Society & Is the role of civil society recognised? Are there clear procedures & 3 \\
\hline
\end{tabular}




\begin{tabular}{|c|c|c|c|}
\hline & & $\begin{array}{l}\text { for the participation of civil society? Is the participation } \\
\text { institutionally arranged or ad-hoc? Does civil society participate } \\
\text { in Joint Sector Reviews and/ or sector working groups? }\end{array}$ & \\
\hline 29 & Donors & $\begin{array}{l}\text { Is the role of donors recognised? Are there clear procedures for } \\
\text { the participation of donors? Do donors participate in Joint Sector } \\
\text { Reviews and/ or sector working groups? }\end{array}$ & 4 \\
\hline \multicolumn{4}{|c|}{ 6. Use of M\&E outputs } \\
\hline 30 & M\&E outputs & $\begin{array}{l}\text { Are relevant } M \& E \text { results presented? Are results compared to } \\
\text { targets? Are discrepancies analysed? Is the M\&E output adapted } \\
\text { for different audiences? }\end{array}$ & 3 \\
\hline 31 & $\begin{array}{l}\text { Effective use of } \\
\text { M\&E by donors }\end{array}$ & $\begin{array}{l}\text { Are donors using the outputs of the sector } M \& E \text { system for their } \\
\text { information needs? Is the demand for M\&E data from donors } \\
\text { coordinated? }\end{array}$ & 4 \\
\hline 32 & $\begin{array}{l}\text { Effective use of } \\
\text { M\&E at central } \\
\text { level }\end{array}$ & $\begin{array}{l}\text { Are the results of } M \& E \text { activities used for internal purposes? Is } \\
\text { it an instrument of policy-making and/or policy-influence and } \\
\text { advocacy at central level? }\end{array}$ & 3 \\
\hline 33 & $\begin{array}{l}\text { Effective use of } \\
\text { M\&E at local } \\
\text { level }\end{array}$ & $\begin{array}{l}\text { Are the results of M\&E activities used for internal purposes? Is } \\
\text { it an instrument of policy-making and/or policy-influence and } \\
\text { advocacy at local level? }\end{array}$ & 2 \\
\hline 34 & $\begin{array}{l}\text { Effective use of } \\
\text { M\&E by } \\
\text { non-government } \\
\text { actors }\end{array}$ & $\begin{array}{l}\text { Are the results of } M \& E \text { used as an instrument for holding the } \\
\text { government accountable? }\end{array}$ & 2 \\
\hline
\end{tabular}

Scoring system (LEADS): 1= little action, 2= elements exist, 3=action taken, 4=largely developed, $5=$ sustainable.

\section{Copyright Disclaimer}

Copyright reserved by the author(s).

This article is an open-access article distributed under the terms and conditions of the Creative Commons Attribution license (http://creativecommons.org/licenses/by/3.0/). 